\title{
Resistance and Representation in Amharic Folk Poetry (1889-1974)
}

\author{
Melakneh Mengistu \\ Addis Ababa University, Addis Ababa, Ethiopia
}

\begin{abstract}
Amharic folk literature is a time-honoured tradition dating back to the imperial songs of the 14th and 15th centuries. One of these subgenres is Amharic folk poetry which is permeated with the political, social, economic, and cultural legacies of successive Ethiopian governments that rise and demise. The image of these governments was determined by their integrity, vision, and responsiveness to the aspirations of the populace. This study was designed to determine the popular image of the imperial governments of Menelik II and Haile Selasse I as reflected in Amharic folk poetry. Without prejudice to some odes which invariably idealise the vision of these monarchs, the politically-inspired Amharic folk poetry is found to be critical of the feudal status quo thus perpetuating its negative images. This underpins the partial unpopularity of Menilik and Haile Selasse. However, these critical gestures would by no means undermine their monumental contributions to the reunification, modernization, and survival of Ethiopia. Thus, the contemporary Amharic folk-poetry is neither iconoclastic nor idealistic but an impassioned allegory of the nation-state.
\end{abstract}

Keywords: satire, modernization, national reunification, Amharic folk poetry, resistance and representation, patriotism, centralization

\section{An Overview of the Imperial Period (1889-1974)}

The reigns of Menelik II and Haile Selasse I mark the second half of the imperial period in the modern history of Ethiopia. Menelik II who emerged as one of the key actors in the power struggle among the northern princes and regional lords was consecrated and crowned the Nəgusä Nägäst (King of kings) of Ethiopia in 1889 and is still regarded as the pioneer of modernization whose innovations are unprecedented in the history of Ethiopia.

By extension, the reign of Menelik coincided with the advent of colonialism whose topical agenda was the Scramble for Africa ${ }^{1}$. More specifically, the colonial ambition of Italy over East Africa dated back to the opening of the Suez Canal which transformed the commercial and strategic significance of the Red Sea coast (1869). After 16 years of manoeuvre, the Italians established themselves at the Red Sea port of Massawa in 1885, as a prelude to their penetration into the Eritrean and Ethiopian highlands (Jonas, 2011). According to historians like Prouty (1986), the distortion of Article 17 of the bilingual Treaty of Wučale ${ }^{2}$ is believed to have

Melakneh Mengistu, Ph.D., Asst. Professor of Post-Colonial Literature, Department of Foreign Languages and Literature, Addis Ababa University.

${ }^{1}$ The scramble for Africa refers to the topical agenda of the Berlin Conference (between 15November 1884 and 26 November 1885) aimed at the partition Africa among the colonial powers without bloodshed (see De Blij \& Muller, 1997).

2 The Italian version of the text stated that Ethiopia was obliged to conduct all foreign affairs through the Italian authorities, in effect making Ethiopia an Italian protectorate whereas the Amharic parallel merely had given Ethiopia the option of communicating with third powers through the Italians. This treachery is believed to have triggered the Battle of Adwa. 
triggered the Battle of Adwa. Menelik II was one of the most patriotic Ethiopian monarchs who mobilized thousands of compatriots against Italian aggression and spearheaded the anti-Fascist campaign.

The victory of Adwa over Italian Fascism is regarded not only as a national pride but also as an incarnation of Black African independence. Thus, the liberation movements which mushroomed in sub-Saharan Africa in the 1960s were allegedly inspired by Ethiopia's symbolic victory over Italian Fascism. This historic phenomenon is discernible from the prismatic colours of the national flags of 21 sub-Saharan countries which are modelled on the tri-colour flag of Ethiopia. The most important contribution of the Amhara elite to Ethiopian civilization and to the survival of that civilization is said to be their struggle to safeguard the independence of Ethiopia and to protect her territorial integrity from foreign aggressors (Fəqre, 1993, p. 23).

Following the victory of Adwa, Menelik embarked on an aggressive, at times brutal, westward, and southward expansion, subjugating and incorporating Oromo, Sidama, Garage, Wälatya, and other groups into his empire (International Crisis Group, 2009, p. 2). This campaign was intended to reclaim or expand the Ethiopian territory in reaction to European encroachment on its peripheries (Tesfaye, 2017, p. 43; Assefa, 2007, p. 114).

During the expansionist conflict, some atrocities have been allegedly committed on the local community and the rebellious kings who were unwilling to compromise over their regional autonomy. Consequently, his administration suffered internal conflict and armed confrontations with defiant regional kings ${ }^{3}$.

Thus, it is not uncommon to hear disparaging remarks or uncomplimentary write-ups about the decisive battles of Č̈länqo, Embabo, Hadiya, Wälayta, Harar, and Käffa waged by Menelik and his brave generals (Jonas, 2011). Some hardliners thus disguise their real motives and distort facts and figures to denigrate the legendary heroes like Gobänna Daçi. Most of the arguments, however, remain to be groundless and politically-motivated that the hands of the warring parties were smeared with blood during the offensives and the counter-offensives (Assäfa, 2007, p. 15; Pankhurst, 1997, p. 28; Jonas, 2011; Bäwuqätu, 2015, p. 18). The other regional kings who submitted peacefully without prejudice to their regional autonomy did not experience the fratricidal wars.

According to Fəqre (1993), Menelik II, who belonged to the Amhara royalty of the Solomonic Dynasty based in Shewa, achieved with extraordinary wit, humanism, diplomacy, and military strategy what both Theodros and Yohannes failed to achieve by sheer use of force (p. 6). Menelik is perceived as a visionary king who accomplished the dreams of Theodros and crafted the geopolitical map of modern Ethiopia (Harding, 1902).

The centralization drive and the repressive tradition of the imperial governments were more consolidated than ever under Haile Selasse I (1931-1974), who is known to have unveiled the first Ethiopian Constitution to refocus governmental power to his legendary Solomonic line or invest an aura of legitimacy to the claim ${ }^{4}$. Most of his loyalty was fostered by the expansion of educational and medical institutions, infrastructural development, and economic sectors like banking and insurance.

However, the modernization dream of Ethiopia was interrupted by the Italian aggression of (1935-1941) which was unleashed after 40 years of military build-up including the recruitment of about 25,000 Eritrean

\footnotetext{
${ }^{3} \mathrm{Had}$ it not been for language barrier, a number of couplets would have been reproduced to evoke the atmosphere of the period.

4 This kind of theocracy was highlighted in the Revised Constitution of Ethiopia (1948/55, pp. 2-3) and states that "That by virtue of his imperial blood as well as the anointing which he has received, the person of the Emperor is sacred; his dignity inviolable and his power is indisputable".
} 
soldiers. In addition to armed confrontation, the Italians were exploiting three dubious tactics to quell the Ethiopian resistance and attract opportunistic collaborators. These were the power struggle among the local contenders, the traditional religious differences between Christians and Muslims, and the resentment of Southern and Northern People against the Central Government (Aregawi, 2015, p. 13), which, in fact, did not materialize.

Consequently, about 300,000 Ethiopian forces had launched a counter-offensive on various fronts against invaders which unflinchingly lasted for seven months. Unfortunately, however, they were betrayed by their compatriots in the eleventh hour (Parlasak, 1989; Täçane, 2010, pp. 293-294).

Being unable to withstand the aerial bombardment charged with mustard gas (chemical weapons), the Ethiopian forces retreated southwards. Had it not been for this internal sabotage, the victory of Adwa would have been repeated at the Battle of Mayĉäw. Subsequently, Italy annexed Ethiopia and Somalia under Africa Orientale Italiana (1936-40) and established five ethno-linguistic administrative regions ${ }^{5}$.

The Emperor, who fled the country in the wake of this national tragedy to preserve a government in abstentia, had made an impassioned appeal to the League of Nations ${ }^{6}$ on 30 June, 1936 in pursuit of military and diplomatic assistance which ultimately gained support with the Allied Forces, notably the USSR (Union of Soviet Socialist Republics) and the USA.

The post-war period was characterized by a range of national reconstruction endeavors like the establishment of educational, financial, medical institutions, military and civil aviations, printing press, military academies, the Ethiopian Highway Authority, and manufacturing industries (Calapham, 1987) with the generous financial and technical support of the US Government.

In spite of such progressive efforts, the Government of Haile Selasse was susceptible to sporadic demonstrations and popular uprisings attributed to misguided socio-economic policies and pervasive corruption (Clapham, 1987). One of the reactions against the status quo was the abortive military coup d'état of 1961 spearheaded by Brigadier-General Mängistu Noway ${ }^{7}$. Over the following decade, the Student Movement ${ }^{8}$ which was radicalized by the Marxist-Leninist and Maoist ideologies of the Eastern Bloc had couched demands for democratization, land reform, the right for national self-determination, pay rise, and the revocation of the Education Sector Review Programme?

\footnotetext{
5 This region which was restructured on the basis of ethno-linguistic models comprised five administrative regions (Eritrea $=$ Eritrea + Təgray); Amhara $=$ Gondär + Goğğam + Wällo + Northernhewa); Scioa + AddisAbaba; Oromo + Sidama $=$ South Western Ethiopia) and Somalia = Jijiga + Somalia). Surprisingly enough, the so called federal structure of the incumbent government appears to be the replica of Italy's colonial map for its ethno-linguistic modalities.

6 The full text of his speech could be accessed from various websites or documents like Time (magazine) 6 January 1936 which had featured the emperor's picture on its front cover under "Man of the Year".

7 The abortive military coup spearheaded by Mängistu Näway, Commander of the Imperial Bodyguard was attempted in December 1961 when the emperor was on a working visit in Brazil. This was perhaps the first progressive anti-feudal movement aimed at reforming the socio-economic structure of the country.

${ }^{8}$ The Student Movement refers to the progressive organizations of Ethiopian students of the 1960 and 70 s both at home and abroad which were bent on demolishing the feudal order. The most dominant wings were the University Students Union of Addis Ababa (USUAA) and the Ethiopian Students' Association in North America (ESANA). Their application of foreign models to resolve the indigenous problem seems to have plunged the country from the frying pan into the fire.

9 The Education Sector Review Report was an ill-motivated education reform policy proposed by the imperial regime in the 1960 s to constrict the educational process to match the limping pace of the economy. It recommended further educational expansion to be limited to a primary level of practical rather than academic orientation. The secondary level was to retain its scope while tertiary education was to expand slightly.
} 
The cumulative effect of these oppression found its expression in the mobilization of the masses under the slogan "Land to the Tiller" voiced by the student activists of the 1960s:

The fundamental driving force of history and thus Ethiopian history as well, is the bitter struggle between the ruling classes and the oppressed classes... [and] because our world outlook is based on the class nature of Human societies, the purge of our feudal legacy is imperative. (Wubneh \& Yohannes, 1988, p. 37)

Thus, the government's failure to respond to the public demands since the $1960 \mathrm{~s}$ is believed to have provided the backdrop against which the February Revolution of 1974 broke out. Given this backdrop, the present study was intended to answer the following research questions:

(1) What was the public perception of the reigns of Menelik II and Haile Selasse I?

(2) Was the politically-motivated Amharic folk poetry characterized by conformism or non-conformism with the status quo?

(3) How did the public respond to the socio-economic and socio-political drives initiated by both governments?

\section{Literature Review}

Ethiopia is characterized by ethno-linguistic diversity and multi-culturalism that it has been well styled as un museo di popoli ${ }^{10}$. One of these ethnic groups is the Christian Amhara inhabiting north-western highlands and central Ethiopia and is perceived as the $\operatorname{Brahmin}^{11}$ of the country by certain parochial groups and demagogues.

Amharic which became the dominant language of Ethiopia by the accidents of history (Bender, 1983, $\mathrm{p}$. 48) abounds in a range of oral traditions dating back to antiquity. One of these genres is folk literature which prevails in preliterate societies and is transmitted from generation to generation by word of mouth. Folk literature which is interchangeably used with oral literature could also be collectively defined as:

Those utterances, whether spoken, recited or sung, whose composition and performance exhibit to an appreciable degree the artistic character of accurate observation, vivid imagination and ingenious expression. (Nandewa \& Bukenya 1983, p. 1)

Levine (1965) corroborated this view with the following assertion:

The genius of Ethiopian peasants is visible in their stories, songs, verses and proverbs...that make up their oral literature. Within the oral tradition, a good deal of original expression and social commentary are found especially in verse. (Levine, 1965, p. 269)

Folk literature is employed as a means of recording pre-history, escaping mechanism, social harmonization, cultivating traditional wit and wisdom in addition to its pedagogical and explanatory functions. In the contemporary world, it is also employed as a means of reforming behavioural and social wrongs like corruption, nepotism, discrimination, injustice, and military crackdown. All the more, folklore is not only an echo of the past but also gives a fascinating sense of continuity with the present in both pleasure and wisdom (Boswell \& Reaver, 1962, p. 11).

${ }^{10}$ Un museo di popoli: This euphemistic description which meant the museum of nationalities was first coined and popularized by Conti Rossini and is cited in J. P. Trimingham (1952), Islam in Ethiopia (p. 2).

${ }_{11}$ The Brahmin are the highest of the four Hindu castes, made up of priests and scholars of Vedic literature and their traditional occupation is to concern themselves with the spiritual guidance of the people, conduct rites at marriages, births, deaths and other auspicious occasions 
Folklore scholarship aims at a systematic collection, analysis, documentation, and popularization of oral treasures before their oblivion. Many folklorists have thus reiterated the significance of the role played by Amharic folk poetry especially in traditional societies. The existing corpus of literature reveals that the study of Amharic folk poetry in the context of socio-economic phenomena unfolding under the imperial and the post-Revolution Ethiopian governments had captured the attention of certain scholars. Amongst these were Shibeshi (1986) who dealt with famine-inspired Amharic folk poetry set against the periodic drought and the attendant resettlement schemes both before and after the February Revolution of 1974 with a particular reference to the former Wällo Governorate General.

Similarly, Fäkade (1998) has examined the peasant response to the recurrent drought which had stricken northern Shewa in 1984/5. He asserted that the primary objective of the study was to determine aspects of the famine of 1984/5 and work up an indigenous conception of the peasant response to periodic famine.

In the same vein, Getahun (1984) has surveyed the reaction of the Peasants' Cooperatives to the maladministration of this enterprise between 1981 and 1987 in which case corruption and swindling were rampant. Recently, Getie (2002) also dwelt upon the peasant response to the land redistribution policy of the Military Government with reference to eastern Goğğam. Even though the Proclamation Providing for the Nationalization of Rural Land was greeted with enthusiasm; Getie underscored the implementation abuses from which it suffered. As a sequel to his previous study, Getie (2002) underpinned the persistent corruption of EPRDF (Ethiopian People's Revolutionary Democratic Front) core functionaries more aggressively with reference to the attendant grievances of the peasantry in eastern Goğğam. Admasu (1980) has also published a slender anthology of Amharic Folk poetry entitled Yämar Eshät (flavoured verses) which encapsulates multidimensional themes ranging from protest against serfdom to war chants.

Similarly, Zäwdu (1986) and Tesfaye (1997) have surveyed the pros and cons of the Därgue (the Military Government of Ethiopia and EPRDF) as reflected in Amharic folk poetry. The former compares the attitude of northern Shewans towards both governments while the latter deals with the reaction of Däbrä Taboreans against EPRD and Därgue (both of which reflect a rising frustration and disillusionment with these governments).

In spite of their endeavor, the foregoing scholars seem to have limited the scope of their studies to a particular region and phenomenon. The present survey, however, makes a modest attempt to reconstruct a panoramic vision of protest tradition in Amharic folk poetry with accents on the reigns of Menelik II and Haile Selasse I.

With regard to methods and procedures, the sample data were gathered during the fieldwork in Goĝgam, Gondär, northern Shewa, and north-western Wällo on various occasions like secular and religious holidays. Some of these were funeral ceremonies, weddings, and cattle herding routines, observances, and seasonal festivals. Some of them were retrieved from documents. Published and traceable sources have been duly acknowledged while the rest of the data gathered randomly from informants or the crowd have been ascribed to the "anonymous sources".

The couplets are virtually untranslatable for lack of rhythmic and lexical equivalence. In this context, Bukenya, Kabira, and Okombo (1994) maintained that "reading poetry in translation is like kissing a girl through a veil" (p. 16). Despite that pessimism, an attempt has been made to recreate, the central gist of each couplet/quatrain if not its poetic flavour and charm. For the benefit of the non-Ethiopian readers, the Amharic texts have been transliterated and italicized to mark them off from their English parallels. 


\section{Post-colonial Resistance in Amharic Folk Poetry}

Historically, the Amhara people had an imperialistic, militant, and expansionist governments headed by highly capable emperors directing armies with superior military strategies. Much of their folklore idealizes the image of Amhara warriors from Amdäşion to Haile Selasse who are known to have vanquished their enemies in historically attested times.

One of these incidents was the historic Battle of Adwa which culminated in the symbolic victory of Ethiopians over Italian Fascism. The vanguard of this victory was Menelik to whom the following resonant couplet is dedicated:

Menelik täwäldo bayanäsa gaŝa

Gəbru ənqulal näbär yehən gize Habäŝa

Had it not been for the birth of Menelik and his counter-offensive

Habäŝa would have been subjected to Fascist bondage

This memorable couplet underpins the significance of the victory of Adwa over Italian army and projects what otherwise the post-war scenario of the country under Fascist rule would have looked like.

Regarding the sustained impact of this victory on the liberation movements of other Black African nations, many historians hyperbolically asserted that:

Ethiopia's prestige in Africa consequent upon her triumphant success against White invasion, and in having remained unconquered throughout the centuries is practically unfathomable... She stands as a granite monument, a living exponent and testimony of the innate puissance of the Black race, the shrine enclosing the last sacred spark of African political freedom, the impregnable rock of Black resistance against White invasion and a living symbol of Black pride! (Thwainte, 1936, p. 207)

In connection with the victory, it is worth citing a couple of war chants which glorify the exploits of patriots and martyrs amongst which were Fitwarari Gäbäyähu,... Balca Abba Näfso, Ras Michael, Alula, Mängäsha Səyum and Mängäsha Jämbäre, Mäkonnən, Täsama Nadäw, Habte Abba Mäla, and Empress Taitu.

Yädaňňäw aŝkäroć hulum loga loga

Sihedu bäfäräs simäläsu baləga.

Dañnaw's fighters all of whom are elegant

Depart on a horseback and return on a stretcher. (Mahtämä Səlasse, 1962, p. 855)

Among the couplets dedicated to Gäbäyähu and his successor Balĉa Abba Näfso who were valiant fighters include:

Yä Adwan Səlasse țälat aräkäsäw

Gäbäyähu bämote gəbana qädəsäw

The enemy has profaned the Adwa Trinity,

For goodness sake, Gäbäyähu restore its sanctity!

Gäbäyähu bimote tätäka Balĉa

Mädəf agälabaç bəĉa läbəĉa. (Mahtämä Səlasse, 1962)

When Gäbäyähu heroically died at the battle ground

Balča took over the cannon with a heroic calibre. 
Among a host of unsung national heroes, some of them are too legendary to be forgotten for their incredible adventures at the war front. In fact, the list of heroes and patriots who paid in blood for the survival of Ethiopian independence is inexhaustible.

The victory of Adwa is cumulative effect of the concerted efforts of all the vanguard forces, the Church, the women folk, the selfless infantry and cavalry. The ethnic-make up of Menelik's army is a testimony of the multi-national structure as well as unity in diversity. This collective consciousness was reflected in couplets like:

Ťalian bäwäçäfow sikora sikora

Dəfən yabäŝa säw qollaw bäwujigəra

Though Italians were bragging of their artillery

The whole Habesha roasted them with traditional guns

The Battle of Adwa has claimed thousands of lives on both sides in addition to incalculable loss of property. The gravity of this holocaust was described as:

YäTəgren buqaya aləbälam srme näw

Yä Adwan buqaya aləbälam 3rme näw

Yäräsäw mätəräyäs yabärayäw bomb näw

Never shall I taste the produce of Təgray

Never shall I taste the produce of Adwa

For it was ploughed with machine gun and threshed with bombs

Certain demagogues criticize Menelik's hesitation to decolonize Eritrea from the yoke of Italian protectionism. But the Italian control of Bahəra Nägaŝ which they renamed it "Eritrea" thus making it one of its colonies in East Africa dated back to 1890 (Assäfa, 2008, p. 3). Assäb was also declared the protectorate of Italy during the reign of Yohannes when Menelik was only the King of Shewa.

All the more, the country had been afflicted with natural disasters like famine and animal epidemics that Menelik's army was incapacitated in terms of logistics and supplies coupled with unprecedented holocaust which had struck the country (Afäwärəq, 1901, pp. 101-102; Amsalu, 2015, p. 22). Thus the critical gesture against Menelik appears to be politically-motivated rather than the quest for national unity ${ }^{12}$. If their concerns were genuine, why do these critics outcry against the dissolution of the Ethio-Eritrean Federation or the reunion of Eritrea with its natural motherland in 1962 (Zäwde, 1998)?

By the accidents of history, the ordeals of Menelik II and Haile Selasse were identical with regard to protecting the territorial integrity of their country. In reaction to the Fascist invasion of 1936, the Emperor had launched a counter-offensive against invaders which unflinchingly lasted for seven months. In the spirit of Adwa complex, hundreds and thousands of gallant compatriots were involved in the Battle of Maycäw. The selfless gallantry of patriots has been juxtaposed with the abominable defection of traitors in the popular war chants like:

\footnotetext{
12 At least, the criticism should have been squarely directed against both emperors rather than defaming Menilik (see also Assäfa's article, "Menelik Eritrean läțaliyan ŝața yämiläwun yätäğ bet ware snəy" reproduced in Times, 28 September 2008 E.C.).
} 


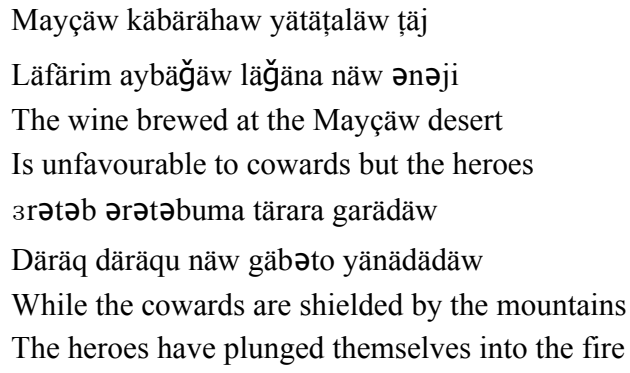

By implication, the daring and courageous heroes have fallen victims of the war like a flammable dry wood while cowards or traitors have been shielded from the flame. Most of the fighters have paid in blood for the survival of Ethiopia while certain collaborators ${ }^{13}$ are known to have betrayed their country in the midst of a decisive cross-fire with the enemy.

Far-sighted compatriots had forewarned their comrades about the imminence of sabotage posed by the double-dealers as follows:

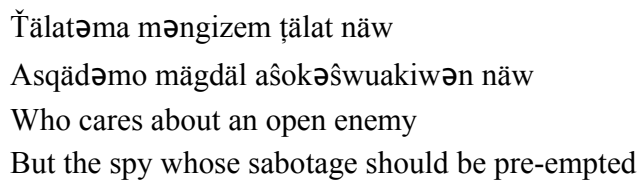

When the prospect of conventional warfare proved to be futile upon the disruption of the national command structure, the spirit of underground resistance was alternatively intensified across Təgray, Gondär, Goğğam, Wällo, Arssi, Wälläga, and Illubabor and other regions inflicting heavy loss on the Fascist army (Arägawi, 2015, pp. 8-10; Haddis, 1985; Bahiru, 1993). Along with the die-hard patriots all over the country, the Ethiopian Orthodox Church symbolised by the martyrdom of Abunä Petros (Bishop) was also courageously marching the streets of Addis Ababa renouncing the incursion of Italian Fascism. The Ethiopian female clandestine patriots and members of the Black Lions Organization ${ }^{14}$ were also actively engaged in the underground resistance movement (Campbell, 2010; Minale, 2001).

The spirit of defiance had escalated beyond the Ethiopian border like Rome itself where heroic Ethiopians were held prisoners. Some of the most memorable patriots were Zärai Däräs and Abdissa Agga who courageously evoked their comrades and Emperor in the presence of Fascist generals in Rome (Näga, 2001, pp. 96-97).

Though public opinion seemed to be divided over the mission of the emperor's flight to London, most of the patriots were confident of his victorious return:

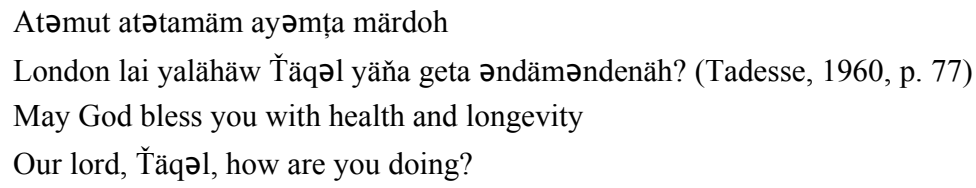

\footnotetext{
13 Among the opportunistic collaboraters were Ras Hailu Täklä Haymanot of Goğğam, Däğğazmać Haile Selasse Gugsa of Təgray, Däğğazmać Hosana Jote of Wälläga, and Sultan Hamfre of Afar to which power-sharing was promised.

14 The Black Lions Organization was an anti-fascist resistance movement directed against the Italian Occupation of Ethiopia during WWII. Its founding fathers like Ras Abäbä Arägay, Hiruy Wälda Səlasse, and Yilma Däressa among others have contributed towards forging a coherent ideological and political direction to the patriotic struggle.
} 
Along with the diplomatic campaign abroad, the anti-Fascist determination of the heroes at home was incredibly stronger than ever that they had vowed to sacrifice their lives(Tadesse, 1960, p. 57; pp. 78-79).

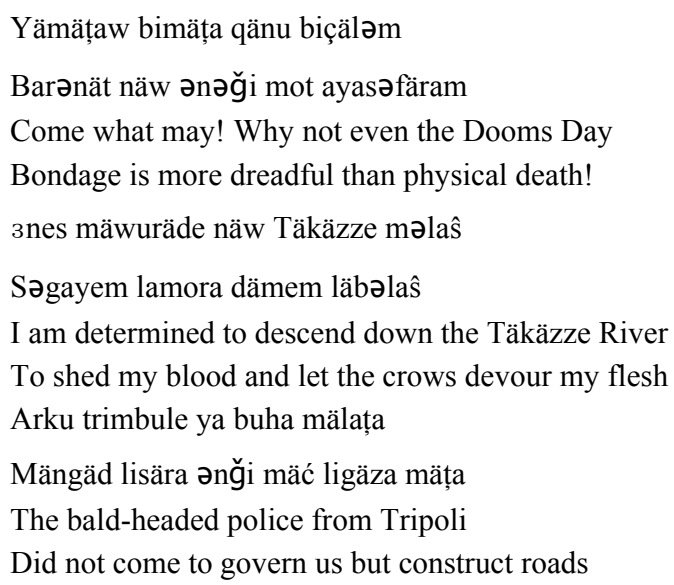

Thus, the determination of the country folk, the inviolability of political sovereignty and territorial integrity, and the sanctity of religion were reiterated. The patriots' commitment to the cause of national independence was also consummated with the following rhetorical question:

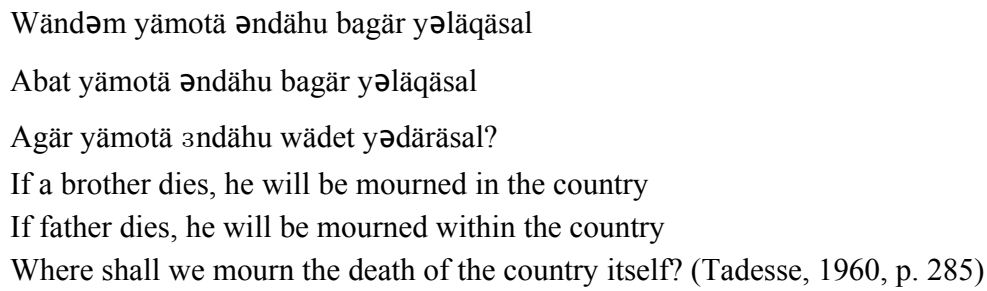

Thus, any compromise over the sovereignty of our country was unthinkable as a token of collective national consciousness irrespective of religious, racial, and ideological differences. Incidentally, the dire need for national unity and the scenario of a divided country was also projected not only by the public but also writers in exile like the late Yoftahe Negusse:

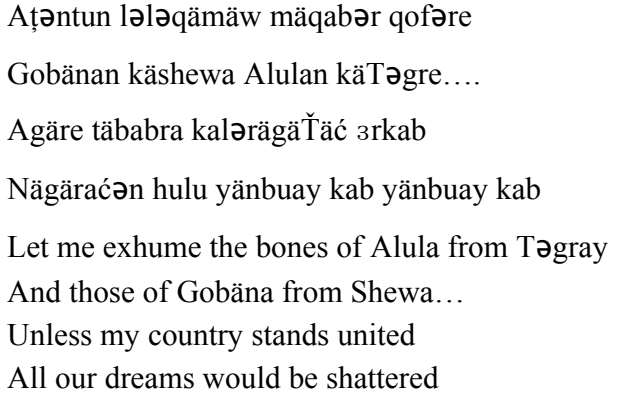

Such a national call is still relevant and topical for the national unity of Ethiopia under the umbrella of democratic governance. Unity in diversity from the tip of Ras Kassar (northernmost) to Moyalle (southernmost) and from Omedlla (westernmost) to Gijiga (easternmost) was discernible from the composition of patriots who were drawn from all walks of life and corners of the country. In the above quatrain, the reference to Gobäna, 
who is the hybrid of the Amhara-Oromo ethnic group and Alula, who belongs to the Tigrean ethnic group symbolizes the multinational structure of the Ethiopian army. Gobäna was a brave General who commanded respect and recognition in Menelik's court whereas Alula was the victor of the Battle of Dogali where Italians were crushed in 1887.

On the other hand, certain groups like Qädamay Woyane ${ }^{15}$ who had mistaken the Emperor's diplomatic campaign abroad for cowardice, slanderously criticized him as:

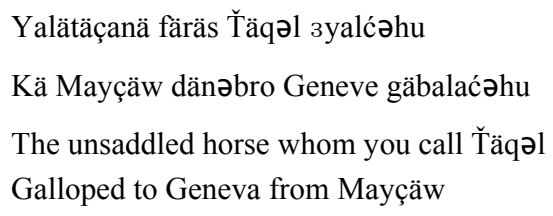

By implication, the Emperor did not live up to the reputations of Theodros, Yohannes, and Menelik. He should have instead reorganized and mobilized Ethiopian patriots against fascist invaders on the central, western, and southern fronts. In fact, the Emperor is known to have left the country with the consent of the Council of Ministers which entrusted him with the sole responsibility of waging a diplomatic campaign overseas (Campbell, 2010, p. 450).

\section{The Irony of Independence}

As stated in the foregoing subsection, Ethiopia regained its national independence from Fascist Occupation on 5 May, 1941, which marked the return of the Emperor from exile to Addis Ababa with foreign detachments and his re-instalment on the Ethiopian throne after a five-year diplomatic offensive abroad. In tandem with the post-war development ventures of the new government, promotions, appointments, and decorations were also conferred on a host of war veterans and loyal servants. However, the recognition accorded to patriots was rather nominal.

Thus, the post-independence protest was directed against the irony of independence in which case the bandas $^{16}$ were rewarded and created provincial governors at the expense of the patriots, guerrilla fighters, and martyrs. This is voiced in a resonant couplet which has become legendary:

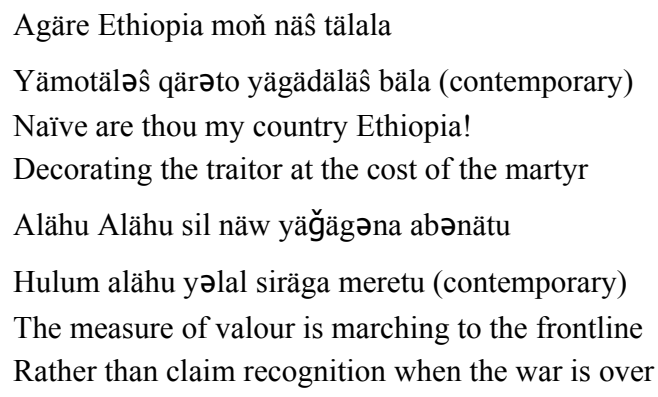

\footnotetext{
${ }^{15}$ Quädamay Woyanne refers to the Tigrean Rebellion of 1943 which seems to have arisen when administrative corruption and greed ignited a situation of existing instability and sense of insecurity. Their motto was inter alia "Our governor is Jesus Christ... and our flag that of Ethiopia; our religion is that of Yohannes IV; People of Təgray follow the motto of Woyanne". Subsequently, the rebels suffered aerial bombardment while the Amhara and Təgrean nobles sided with the Emperor whereby order was restored.

${ }^{16}$ Banda (Amharic) is a derogatory term which stigmatises traitors or saboteurs who had betrayed a national cause amid a decisive warfare or diplomatic campaign.
} 
The Emperor was intolerant of patriots who had been waging guerrilla warfare against Fascist invaders in his absence. A specific case in point was the assassination of outspoken heroes like Däghazmac ${ }^{17}$ Takälä W. Hawarəyat and Ləj ${ }^{18}$ Bälay Zäläkä who were critical of his flight to Geneva at the end of the Battle of Mayćäw. Takälä Wäldä Hawaryat is said to have committed suicide in November 1941 when bullets and supplies ran short in the midst of cross-fire with government security forces. Subsequently a certain mourner has thus evoked his heroic fall as follows:

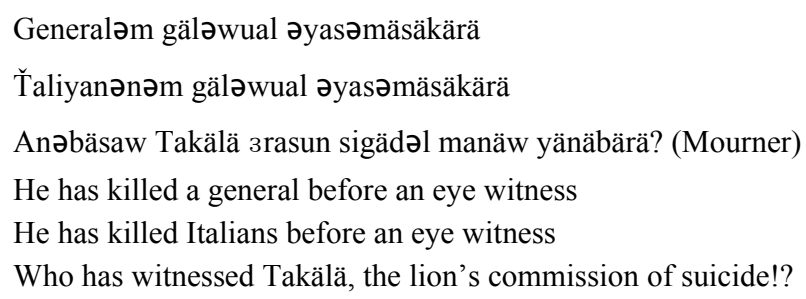

Similarly, the illegal and immoral capital punishment of Bälay who had been waging guerrilla warfare along the Blue Nile Valley against Fascist invaders after the flight of the Emperor was also evoked in the following funeral dirge impregnated with political overtones:

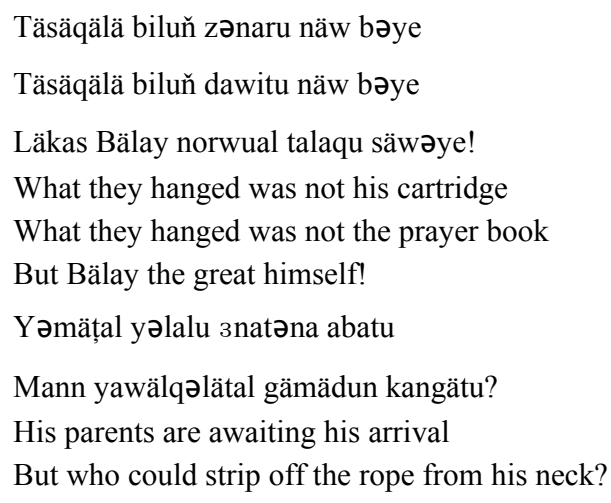

Of all the wrongs committed by the Emperor, the execution of gallant heroes like Bälay (allegedly upon the recommendation of General Wingate), Takälä, and a host of others, is unpardonable by history.

\section{Modernization and Centralization Drives}

According to Crummey (2000), the reunification of Ethiopia after the decline of the Gondärine kingdom began with the rise of Emperor Théodros (1855-1868) under the banner of national reunification and modernization over the debris of Zämänä Mäsafant ${ }^{19}$. Menelik, who followed the foot prints of Theodros, ushered in modernization initiatives like infrastructural development (electrification of towns, expansion of education) and adoption of a central taxation system and the founding of the new capital, Addis Ababa on the hill tops of Mt. Ențoțo.

\footnotetext{
${ }^{17}$ Däghazmač... Literally commander of the door is synonymous with an Earl. In this connection the title Ras is also used to refer to head or Duke of a given country or administrative region.

${ }_{10}^{18}$ Ləğ was a hereditary title which was conferred on the son of the upper aristocracy.

19 Zämänä Mäsafant which was interchangeably used with the Era of princess marks an epoch of balkanization in the political history of Ethiopia before the rise of Theodros during which the affairs of every region were run by their own and autonomous princes/kings.
} 
All the more, the introduction of modern mass media like print journalism with the maiden issue of Aemiro $^{20}$, the telegraph and telephone was initiated by Menelik much against a fierce resistance of the nobility which had associated the products of technology with Satanic ventures. Besides, the introduction of postal service system, the adoption of national currency, and the abolition of slave trade are some of his contributions.

Undoubtedly, Menelik had endeavoured:

To build a nation besides winning the Battle of Adwa in 1896 and keeping the independence of Ethiopia. The end result of his efforts was a unified, peaceful, and expanded empire with a fine infrastructure for the modernization of Ethiopia. (Fəqre, 1993, p. 6)

The dwellers of Addis Ababa had thus greeted such initiatives with enthusiasm as follows:

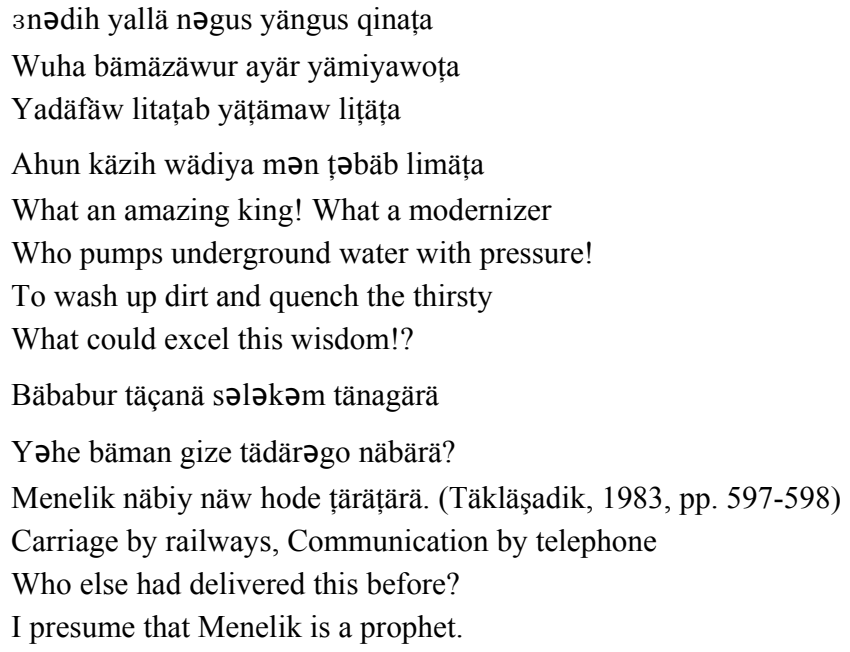

This is reminiscent of the Ethio-Djibouti Railway, the electronic media of communication, and installation of potable water which were initiated by Menelik.

Moreover, Menelik II shouldered the responsibility of restoring ancient Ethiopian Empire which had been balkanized into rival regions as a consequence of Oromo expansion and the destructive Jihad of Ahmed Ibin Ibrahim between 1529 and 1632 (Assäfa, 2007; Taklaşadik, 1966). Thus, his attempt to restore the geo-political map of Ethiopia and to reconstruct annihilated churches was hailed by the compatriots as follows:

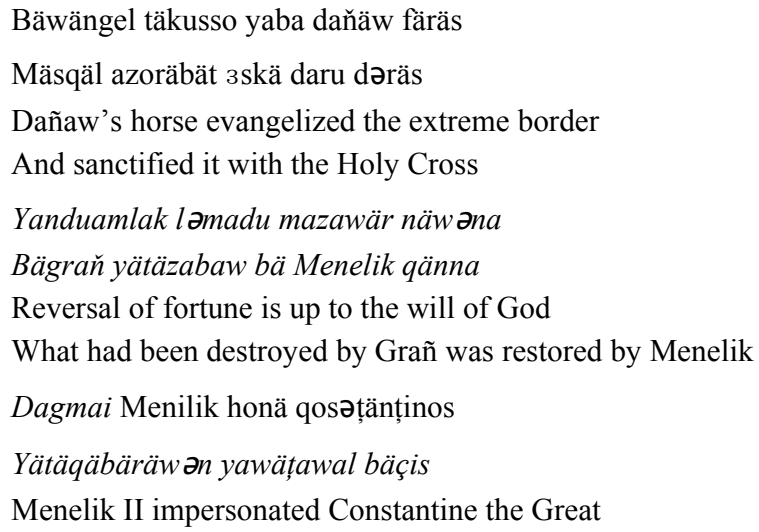

20 Aemiro refers to the first ever published Amharic Weekly News Paper of Ethiopia established around 1889 by Menelik II. 
Who unearthed the submerged Cross. (Täkläşadik, 1966, p. 836)

This is an allusion to the finding of the True Cross upon which Christ was crucified at Jerusalem and with which Constantine's mother, Empress/St. Helena, was credited in Christian mythology. Menelik's partisanship to Christianity was comparable to the evangelization moves of Constantine the Great (312 A.D.) who converted the Roman Empire to Christianity.

Another case in point was the Battle of Embabo ${ }^{21}$ which reflects the power struggle between Menelik and Täklä Haymanot of Goĝgam who were ambitious of expanding their empires southwards beyond the Gibbe River:

Yä Embabon buqaya albälam miyalähu

Yäsäw däm țäțəto mäbqälun awuqalähu

I swear, I shall never taste the produce of Embabo

For it was irrigated with human blood

This reveals that the death toll and the number of causalities on both sides had perhaps reached unprecedented proportions. This was one of the three bloody which led to Shewan supremacy over the rest of Ethiopia (Donham, 2002, p. 23).

In the wake of Täklä Haymanot's death who was defeated in the war but designated as the ruler of Goĝgam, his children were denied of the right to succeed to their father as the heir apparent of the crown. Thus, when an outsider was created the governor of Goĝgam, the natives are known to have revealed their deep-seated resentment against Menelik in the following metaphorical couplet:

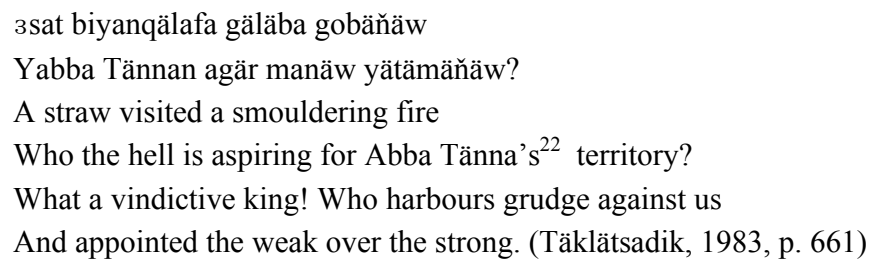

By implication, the reign of Menelik was highly centralized and dominated by the Shewan nobility and aristocracy.

The reign of Haile Selasse was also highly centralized and dominated by the Shewan nobility and aristocracy excluding a handful of appointments and political marriages outside Shewa. For instance, Mahtämä Səlasse (1961) provided a an extended profile list of the nobility and aristocracy in the courts of Menelik II and Haile Selasse I who were predominantly of Shewan origin (pp. 12-94). This kind of marginalization or provincialism was voiced as:

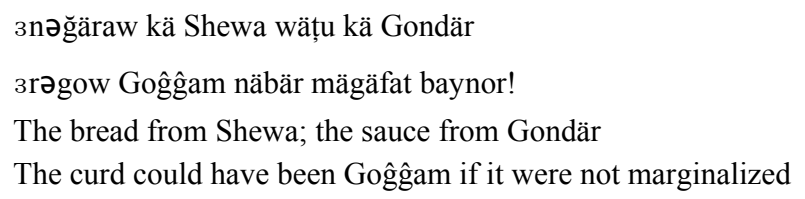

${ }^{21}$ Embabo was the battleground where the bloody conflict between Menelik and Täklähaymanot of Goğğam was waged in 1882.

${ }^{22}$ Abba Tänna... refers to the horse name of Nəgus Täklähaymanot of Goğğam who was contemporaneous with Menelik. It connotes sense of determination. 
The couplets criticize the partiality for bread which metaphorically represents Shewa and Sauce (Gondär) at the expense of Curd (Goğğam). By implication, the marginalization of Goğğam and Gondär from power-sharing in favour of Shewa was supposed to be politically-motivated.

Much later, a similar protest was voiced against Ras Emiru (Duke) Emiru's appointment as a governor of Goĝgam by Emperor Haile Selasse since the former's appointment was considered to be an expression of Shewan domination. Though the elders of Goĝgam maintain that Ras Emiru was a liberal governor, the rudeness of his soldiers was unbearable about which the local people were resentful:

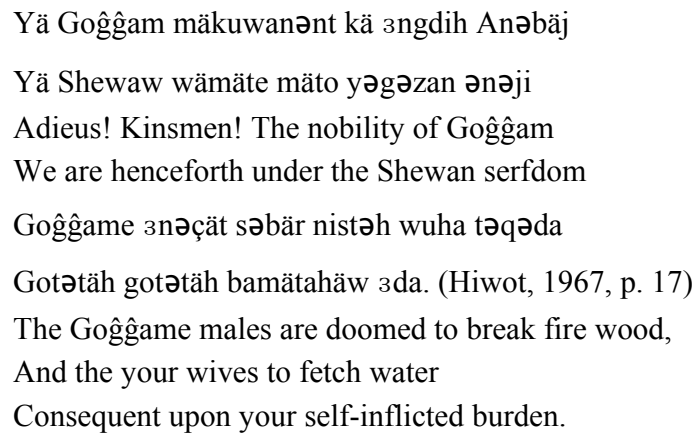

The popular view in this regard has it that the Emperor Haile Selasse was biased against the Amhara ethnic group except Shewa perhaps for political reasons. It is worth mentioning the fatal conflict between Ayalew Birru of Gondär and Bälay Zäläkä of Goğğam and a host of other patriots who were executed after their surrender under the cover of amnesty.

The dissolution of the Ethio-Eritrean Federation 1962 in spite of its unforeseen repercussions was also an aspect of centralization (Zäwde, 1998, p. 502). In the wake of the reunion, the public had voiced its admiration with the following lyric poem:

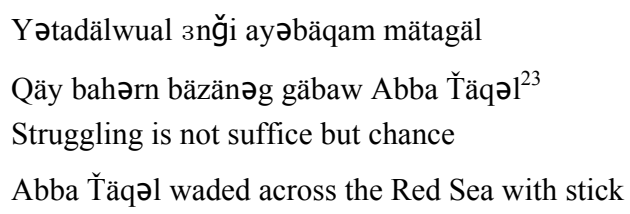

Thus, the reunification of Ethiopia was initiated by Theodros, developed by Menelik and completed by Haile Selasse I, and cherished by Colonel Mängistu Haylämaryam.

\section{Lack of Good Governance/Natural Disasters}

Despite progressive efforts of modernization and infrastructural development, the reign of Haile Selasse I was ridden with bribery and senseless exploitation of the peasantry by the land lords. This is attributed to the enforcement of the gult ${ }^{24}$ system on which the foundation of feudalism was laid. According to Markakis and Negga (1986, pp. 22-23), the aristocratic classes of Ethiopia were...parasitically maintained through the medium of gult which served as a means of surplus appropriation while their producers were reduced to living

\footnotetext{
${ }^{23}$ Abba Ťäqəl refers to Haile Selasse's horse name which connotes his imperial ambition. Abba is also a traditional title conferred on community leaders, horses, and archpriests.

${ }^{24}$ Rist in Feudal Ethiopia was a customary institution invoked by the Solomonic state to confer upon groups or individuals the right to collect tribute from the landed peasantry (see also Crummey, 2001, p. 551; Hoben, 1973, p. 119).
} 
on subsistence economy and the menace of periodic famine since its produce is drained by the gultän̆a who was is entrusted with collecting taxes and produces from the producers and allowed to settle on land grants.

Consequently, there were instances of peasant rebellion as well as popular uproar in Tagray, Goghgam, and Bale administrative regions in the 1960s (Gebru, 1996). The reaction of the embittered peasantry against unbearable taxation bill was evident enough as reflected in the following couplets (Admasu, 1980, p. 78):

Yəgäbər kalaćəhu zənğärom Yəgäbər

Yämänəgəst näwəna yämiçəräw mədər

If the question is one of paying tributes

Let the monkeys also follow suit for they live on government holdings

Much against the practice of tax evasion and avoidance, the survival economy of the tenants coupled with bribery proved to be quite disheartening.

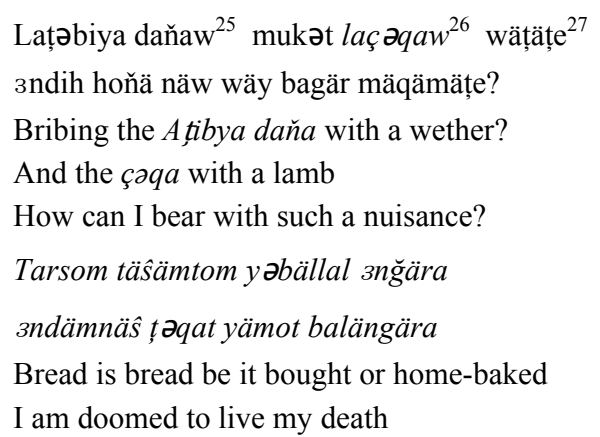

By implication, the protest was directed against the feudal order and calls for solidarity of struggle with fellow countrymen and women. The apostrophe addressed to the Blue Nile implores it to subside so that the comrades in Shewa would cross over to Goğğam and join hands with their compatriots.

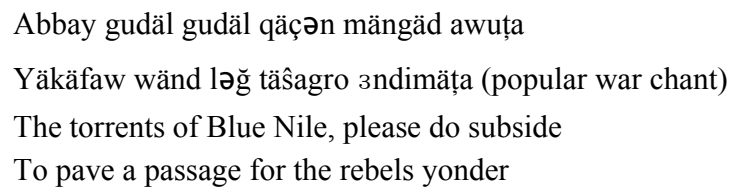

These satirical couplets reflect the impoverishment of the peasantry, the injustice of the government functionaries, progressive tax proposals levied on the tenants, lack of good governance, and the scale of corruption. They were thus the embodiments of pessimism and the resistance of the peasantry against the malpractices of the imperial government of Haile Selasse.

Apart from man-made problems, our fathers and forefathers had thus sustained natural calamities ranging from a seasonal epidemic to a periodic drought. This is perhaps attributed to technological backwardness, reliance on seasonal rainfall, and land degradation.

The gravity of such disasters has been reflected in folk-poetry whose settings dated back to the days of Menelik. The couplets which are markedly famine-inspired include:

\footnotetext{
${ }^{25}$ Atbiya daña ... a lowest local chief entrusted with resolving judicial conflicts at a village level in feudal Ethiopia.

${ }^{26}$ Çəqa. is also the lowest local chief entrusted with collecting agrarian taxes from the local peasantry in the feudal hierarchy.

27 Wäţäțe is a lamb which is fatter and older than lambs.
} 
Läfäräs läbäqəlo yətärəf yänäbärä

Zares läsäw yahəl yəćägər gämärä (Contemporary)

That which used to be in excess of pack animals

Is now short of bare survival

3rabe bähode bäqəlo zäräzärä

3natema bətəhon taçədələn̆ näbärä

Hunger, deep sown in my stomach is flowering

Who else could weed it out except my mother (Shibeshi, 1986)

Ethiopia has always been vulnerable to periodic drought and famine (Mesfin, 1974; Pankhurst, 1997; Paulos, 1984/92). The Great Famine of 1888-1892, the "Unknown Famine" of 1974 which had struck north-eastern Tigray and Wällo and triggered the February Revolution of 1974, and the grip of the 1984 famine nick-named aguriț (monster) which had befallen northern Shewa are some instances of the drought-famine cycle.

The direct consequence of hunger ranges from starvation to a panorama of seasonal migration in pursuit of a daily bread. This phenomenon was prevalent during the reign of Haile Selasse in which case the large scale famine was hidden from the world and the public. However, Jonathan Dimbleby's searing testimonial of human suffering entitled the "Unknown Famine" was released in Britain on 18 October, 1973 (Markakis \& Negga, 1986, p. 81). At least, the Imperial Government could have appealed for international aid to avert the national tragedy migration and dislocation:

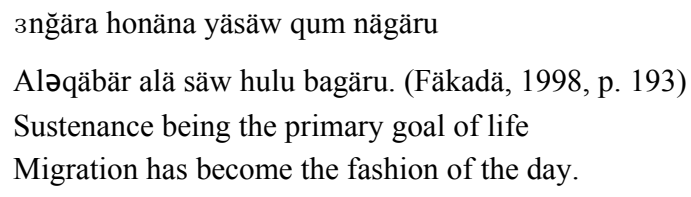

Even today, rural and cross-border migration is one of the topical agendas of the world. Natural disaster could be aggravated by man-made problems like lack of good governance involving, ecological adversity, inequity of resource allocation, nepotism, discrimination, and parochialism, civil war, militarism, and unemployment.

By the same token, elemental forces such as water erosion, torrential rain (heavy downpour) and rivers overflowing their banks are also the butts of protest for claiming many lives and cause a considerable damage of property. For instance, the soil erosion which has coloured the Blue Nile is observed as:

\section{Abbay Ťikur näbär Käsäl yämäsälä зyäqälla hadä Turk зyämäsälä \\ The Blue Nile which used to be as blue as charcoal Has now turned crimson-red. (Mesfin, 1972, p. 54)}

The metaphorical analogy is drawn between the natural serenity of the Blue Nile and its adulteration with soil erosion which came out crimson-red like the skin colour of Turks. In other words, the Blue Nile is no longer clear and serene but dark and impure due to environmental degradation which is detrimental to the agrarian population. Though some natural disasters which have plagued the rural population of Ethiopia could be beyond their control, these governments should have taken rescue measures such as terracing, afforestation, and appeal for humanitarian aid. 


\section{Conclusion}

Since the turn of the 19th century, Ethiopia has experienced the grips of two successive imperial governments under the kingdoms of Menelik II and Haile Selasse I with varying degrees of popularity. Thus, the critical survey of contemporary folk poetry revealed that the popular images of Menelik and Haile Selasse are characterized by duality of perception.

This is discernible from the corpus of folk poetry which idealizes and satirises these visionary monarchs. The values cherished by both monarchs were the ideals of national reunification centralized government, modernization ventures, uncompromising stance on the sovereignty and territorial integrity of the country.

However, these positive images are juxtaposed with iconoclastic overtones which expose the social wrongs of the governments in question like political oppression, economic exploitation, and social class stratification and imperial ambition and power-mongering at the cost of good governance and democratization. At any rate, these monarchs had undoubtedly envisioned an independent, united, and centralized government with all its implications in spite of their time-conditioned limitations.

\section{References}

Admasu, R. (1980). Yämar eshät. Addis Ababa: Ethiopia Book Centre.

Afäwärəq, G. (1901). Dagmawi Menelik Nagusä Nägast zä Ethiopia. Rome.

Amsalu, G. (2015). Yä Adwa Dələna Tərufat Fätänawoću. Fətun, 153, 22.

Aregawi, B. (2015). Spirit vs. war-machine: A patriotic resistance to Italian occupation of Ethiopia (1936-1941). Retrieved 21February, 2018 from http://www.academia/.edu.8619644/

Assäfa, Č. (2008). Menelik Eritrean läŤaliyan ŝața yämiläwun yätäğ bet ware 3nəy. Times, 28, 15.

Assäfa, E. (2007). Ethiopia: YähəzboC'Səbțərna YägäzazoĆ AwäqaqärAçərTarik. Addis Ababa: Bərnanəna Sälam Printing Press.

Bahiru, Z. (1993). The Ethiopian intellegentsia and the Italo-Ethiopian War (1835-1941). The International Journal of African Historical Studies, 26, 2.

Bäwuqätu, S. (2015). Kamen Bashagär. Addis Ababa: Far-East Trading.

Bender, M. L. (1983). The origin of Amharic. Journal of Institute of Language Studies, 1(1), 42-48.

Bərhanu, A. (2005). Yätahəsas Gərgarna Mäzäzu. Addis Ababa: Addis Ababa University Press.

Boswell, G. W., \& Reaver, J. R. (1962). Fundamentals of folk literature. Oousterhout: Anthropological Publications.

Bukenya, A., Wanjiku, M. K., \& Okombo, O. (1994). Understanding oral literature. Nairobi: East African Literature Bureau.

Campbell, I. (2010). The plot to kill Graziani: The attempted assassination of Mussolini's viceroy. Addis Ababa: Addis Ababa University Printing Press.

Clapham, C. (1987). Transformation and continuity in revolutionary Ethiopia. African Studies Centre, Cambridge: Cambridge University Press.

Crummey, D. (2000). Land and society in the Christian kingdom of Ethiopia from the thirteenth to the twentieth century. Urbana and Chicago: University of Illinois Press.

Crummey, D. (2001). Land and society in the Christian kingdom of Ethiopia from the thirteenth to the twentieth century. The Journal of Modern African Studies, 39(1), 551.

De Blij, H. J., \& Muller, P. O. (1997). Geography: Realms, regions and concepts. USA: John, Wiley \& Sons, Inc.

Donham, D. (2002). The Southern marches of imperial Ethiopia. Oxford: James Currey.

Fäkadä, A. (1998). Unheard voices: Drought, famine and god in Amharic folk poetry. Addis Ababa: Addis Ababa University Press.

Fəqre, T. (1993). Amhara Contribution to Ethiopian Civilization. The Ethiopian Review, 4, 17-28.

Fəqre, T. (2008). Yä Oromona Yämara зwunätänaw Yäzär Mənĉ. Addis Ababa: Nebadan Publications.

Gebru, T. (1996). Power and protest: Peasant revolt in the twentieth century. Lawrenceville, NJ: Red Sea Press.

Getahun, A. (1984). Bädäbrä Marqos Awurja səle gäbärewoĉ ähəbrät sra mahəbärat yätägäțämu gəțtomoĉ (senior essay). Addis Ababa: Addis Ababa University. 
Getie, G. (2002). Peasant poetics and state discourse in Ethiopia: Amharic oral poetry as a response to the 1996-97 land redistribution policy. North-East African Studies, 1(6), 171-176.

Haddis, A. (1985). Tizäta (Remembrance). Addis Ababa: Kurazhing Agency.

Haile, S. I. (1936). Appeal to the league of nations. Speech delivered at the League of Nations, Geneva (Switzerland), June.

Harding, G. F. (1902). The campaign of Adwa and the rise of Menelik. Berkley: Negro University Press.

Hiwot, H. (1967). Yaĉ Qän Täräsaĉ. Addis Ababa: Bərnanəna Sälam Printing Press.

Hoben, A. (1973). Land Tenure among the Amhara of Ethiopia. Chicago: University of Chicago Press.

International Crisis Group. (2009). Ethiopia: Ethnic federalism and its discontents. Africa Report (No. 153). Nairobi and Brussels: International Crisis Group.

Jonas, R. (2011). The battle of Adwa: African victory in the age of empire. Cambridge: Harvard University Press.

Levine, D. N. (1965). Wax and gold: Tradition and innovation in Ethiopian culture. Chicago: The University of Chicago Press.

Mahtämä Səlasse, W. M. (1961a). Yamarəña Qəne Känämäfðĉaw. Addis Ababa: Bərnanəna Sälam Printing Press.

Mahtämä Səlasse, W. M. (1961b). Ćä bäläw. Addis Ababa: Commercial Printing Press.

Mahtämä Səlasse, W. M. (1962). Zəkrä Nägär. Addis Ababa: Artistic Press.

Markakis, J., \& Negga, A. (1986). Class and revolution in Ethiopia. Trenton, N.J: The Red Sea Press.

Mesfin, W. M. (1972). An introductory geography of Ethiopia. Addis Ababa: BSPP.

Mesfin, W. M. (1974). Rural vulnerability to famine in Ethiopia: 1958-1977. India: Vikas Publishing House Ltd.

Miknal, A. (2001). Women and warfare in Ethiopia. Addis Ababa: OSSREA.

Näga, T. (2001). Yä Ethiopiawian Yä Räjim Zämänat Təgələna Zämänawi Särawit Amäsärarät (1855-1974). Toronto, Canada: Tana Printers.

Nandewa, J., \& Bukenya, A. (1983). African oral literature for schools. Cambridge University: World Oral Literature Project.

Pankhurst, R. (1997). The Ethiopian borderlands: Essays in regional history from ancient times to the end of the eighteenth century. Lawrenceville, NJ: Red Sea Press.

Parlasak, A. (1989). Habesŝkä Odessea. J. Täĉane (Trans.). Addis Ababa: Addis Ababa University Printing Press.

Paulos, Ň. (1984/92). Aşe Menelik. Addis Ababa: Berhanena Salem Printing Press.

Prouty, C. (1986). Empress Taytu and Menelik II. Trenton: The Red Sea Press.

Rubenson, S. (1976). The survival of Ethiopian independence. London: Heinemann.

Shibeshi, L. (1986). A thematic approach to famine-inspired amharic folk poetry (Unpublished M.A. thesis submitted to the Department of Foreign Languages and Literature, Addis Ababa University).

Täĉane, J. (Trans.). (2010). Yahabäŝa Jäbdu. Addis Ababa: Addis Ababa University Printing Press.

Tadesse, Z. (1960). Yä 'balaŝ̃ñ Zämän. Addis Ababa: Commercial Printing Press.

Täkläșadik, M. (1964). Yä Ethiopia Tarik: Kä Theodros 3skä Qädamawai. Addis Ababa: Bərnanəna Sälam Printing Press.

Täkläșadik, M. (1966). Yä Gərañ Ahmäd Wärära. Addis Ababa: Bərnanəna Sälam Printing Press.

Täkläșadik, M. (1983). Așe Menelikəna yä Ethiopia Andənät. Addis Ababa: Kuraz Publishing Agency.

Täsfaye, A. (2017). State and economic development in Africa: The case of Ethiopia. Palgrave: Macmillan Publishers.

Tesfaye, A. (1997). Bäsämen Shewa; Qäwät wäräda bäDärgəna bä EHAD G mängəstat lay yätäsänäzäru sənäqalawi gətmoc yəzət təntäna (Unpublished senior essay, Department of Amharic, Addis Ababa University).

Thwainte, D. (1936). The seething African pot. London: Constable and Co.

Trimingham, J. S. (1952). Islam in Ethiopia. London: Frankcass C.

Wubneh, M., \& Yohannes, A. (1988). Transitional development on the horn of Africa. Boulder, Colorado: West View Press.

Yä Ethiopia Həgä Mänəgəst (yätäŝâsalä). (1948). The Constitution of Ethiopia, 1955 (Revised). Addis Ababa: Bərhanəna Sälam Printing Press.

Zäwde, R. (1998). Yä Eritrea Guday: 1941-1963 (4th ed.). Addis Ababa: Central Printing Press.

Zäwdu, N. (1986). Bä Däbrä Tabor Akababi Darguənəna EHADGən bämäqawoməna bämädägäf yätägäțämu gəțmoĉ yəzät təntäna (Unpublished senior essay, Department of Amharic, Addis Ababa University). 